\title{
Employee Motivation and the Promotion of Agricultural Enterprise
}

\author{
Mbu Daniel Tambi", Ngefack Edward Azem \\ Department of Agricultural Economics, University of Dschang, Cameroon
}

*Corresponding Author: Mbu Daniel Tambi, Department of Agricultural Economics, University of Dschang, Cameroon

\begin{abstract}
Concern is gradually growing on issues related to workers motivation and agriculture in most enterprises in the world today. This study has as objective to determine the nature of motivation use in the agricultural enterprise and to analyse the extent to which employee's motivation affects production in Cameroon. The Linear production function is used to estimate the results through primary data collected among tea estate personnel blend with secondary data gotten from the statistics department of the Estate. The result shows that the principal motivational practices employed by agricultural enterprises are: increase wages, in-service-training, reward for overtime, recognition, material for protection at work, leave allowance, social insurance and annual leave. Employee motivation is found to be strongly correlating with agricultural production. We recommend that public authority in this sector should augment their level of employee motivation as it enhances agricultural production.
\end{abstract}

Keywords: Contribution, Employee Motivation, Agricultural enterprise, Cameroon

\section{INTRODUCTION}

Concern is gradually growing on issues related to workers motivation and agricultural enterprise in most growing enterprises in the world today. Considering the case of tea production in Cameroon in relation to tea consumption and production, it can be noted that modern tea consumption is rooted in medicinal use since five thousand years ago in China (Bouddih, 2003). Today, it has become the world's most popular drink after water, whose industry employs more than 13 million people around the world. Tea grows well at high altitudes and in mildly acidic lands and can therefore be cultivated in areas unsuitable for other crops. Tea is primarily produced in Asia and Africa, with China, India, Kenya, Sri Lanka and Turkey accounting for 76 per cent of global production. Unlike coffee and cocoa, the majority of tea production is consumed locally, in domestic markets. Nevertheless, $44 \%$ of global production was destined for export in 2011, worth US\$6.6 billion United (Beffes, 2004).

In 2011, 4.7 million metric tons of tea was produced in more than 45 countries on 0.07 per cent of the world's agricultural land. Two million metric tons were exported during the same year through auctions (there is no stock and futures market for tea). The tea supply chain is characterized by vertical and horizontal integration, with a small number of companies controlling the entire tea supply chain, from packing to processing and consumer branding (Dutta, 2011). About 85\% of global tea production is sold by multinationals, three of which control one-fifth of the market: Unilever $(12 \%)$, Tata Global Beverages (formerly Tata Tea, 4\%) and Twinning's (3\%) (Achiri, 2015). Tea was brought into Cameroon in the late 19th Century by the Germans from German East Africa and the seeds planted in the Botanic Garden in Victoria now called Limbe. Due to the various wars the Germans could not develop the tea industry in Cameroon and it was only in 1954 that the development of Tole Tea Estate started in earnest eastern slopes of Mount Cameroon, in the South West Region. In 1952, the Cameroon Government launched the Tole Tea Estate and put it under the Cameroon Development Corporation (CDC) and four years later a small tea production unit of 54 hectares was planted. This developed by 1968 to about 450 hectares with production figures in excess of 1080 metric tons with an annual sale of about USD 1,728,000 (Gana, 2000).

The great success of Tole Tea Estate in producing and marketing tea profitably made the government to create two more tea estates in Ndu and Djuttitsa, in the North West and West regions respectively. 
We also have the Ndawara and the Liko tea which are privately owned and located in the North West Region and South West Region respectively which also specialized in the processing of black tea. The tremendous increase in tea production without corresponding increase in demand in both the Nigerian and domestic markets led to a decrease in prices. These markets were flooded with tea and CDC fetched very low prices on these markets. These tea estates could only survive because of government subsidies on inputs like pesticides, fertilizer, extension service and labour. It then decided to look for new markets where its excess product could be sold. Due to the increasing demand for tea on the European markets, CDC decided to access these markets (Gana, 2000). Several attempts were made by CDC to export tea to the EU markets but were rejected because of low quality. Due to the above ramification, $\mathrm{CDC}$ continued to receive low prices for its tea on the Nigerian and domestic markets and a niche market was found in USA which could only absorb 5\% of its low quality product. The inability of CDC to make profit and the Structural Adjustment Program implemented on demands from the World Bank and the IMF led to its privatization in 2002 to the Cameroon Tea Estate (CTE) who is also the proprietor of the Ndawara Tea Estate (Bouddih, 2003).

Immediately Brobon Finex took over the three plantation they went ahead to create a new tea plantation and company called the Ndawara Upland Tea Estate. In 2004, 928 hectares were planted in Ndawara on the slopes of the North West Highland. Planting continued in 2005, 2006 and 2007. In 2011, Ndawara had 1,643 hectares of young tea and in 2010 it produced 1,366 tons of made tea. Cameroon Tea Estates therefore has three plantations: Tole Tea with 454 Hectares, Ndu Tea with 668 hectares and Djuttitsa Tea with 446 hectares. All three plantations have their factories and produce about 4,500 tons per year. Ndawara has about 1,643 Ha and produce some 1,400 tons per year Production will increase with maturity and is expected to reach 5,000 tons in the next 5 years. It is worth noting that most of Ndawara is planted with clonal material from South Africa and Djuttitsa Tea. All four tea factories in Cameroon are CTC factories (Achiri, 2015). Cameroon therefore has a total of 3211 hectares of tea planted area with about $90 \%$ of made tea sold in the North Cameroon market which extends to a sub-regional market and into Chad and Sudan Middlemen Market with lots of price fluctuations. This market is threatened by cheap tea from China, Malaysia, Kenya, Rwanda and Democratic Republic of Congo. The other 10\% of tea production which is mainly packaged tea (added value) is sold in Southern or Elitist market and also facing stiff competition from China, Indonesia. This brief historical review of tea production in Cameroon shows that tea has remained a relatively minor crop (Achiri, 2015).

Tea is the second most popular drink in the world, after water. For a number of developing countries it is an important commodity in terms of jobs and export earnings. Tea production is labour intensive and the industry provides jobs in remote rural areas. Millions of livelihoods around the world depend on tea picking and processing. However, as with many other agricultural commodities, real primary producer prices have fallen dramatically over the last three decades. Low prices are affecting the sustainability of the tea sector, with working conditions and the livelihoods of plantation workers and small-scale farmers in tea producing countries under pressure. Meanwhile, tea trade and distribution is dominated by a few international companies that benefit from stable retail prices. At the same time, policies, regulations, support services, tax and trade instruments and their associated actors and institutions have also developed to become intrinsic parts of the value chains.

Value chains play an important role in transforming agricultural commodities from raw material to end products demanded by the consumers. There are a number of stakeholders involved in the agricultural commodity value chains and the structuring and functioning and treatment of the actors involved this chain is often debated and analysed. A report by Oxfam in January 2013 revealed evidence of poor labour practices in Unilever's operations in Vietnam between 2011 and 2012. An indepth review by Oxfam showed that: wages were insufficient to make savings or support dependants, with instances of workers unable to eat adequate diets or afford to keep children in school; suppliers and managers unclear about Unilever's codes of conduct, in some cases only accessible in English; factory workers employed by a third party were on much poorer terms and conditions and suppliers with employees working illegal overtime hours. The objectives of the study are: to determine the nature of motivation use in the Djuttitsa tea estate, Cameroon and to analyse the extent to which employee's motivation affects the tea agricultural enterprise.

\section{LITERATURE REVIEW}

As a result of socio-economic variations, the environmental, climatic and demographic diversity of Cameroon, the potentials for agricultural production are quite high. According to Nkwain et al (1993) 
perish-ability and seasonality of most crops, poor marketing system, and inadequate processing technologies to preserve and conserve products, constitute a great challenge to the country. Cameroonian agricultural producers through time have confronted a number of production problems and constraints. These have been identified to include land tenure, cropping systems, technical knowhow, pests/diseases, climatic and demographic problems and constraints (Ayissi et al., 1988).

In Tanzania, it was revealed that; inadequate infrastructure has been a major reason for the tea sector's poor performance and an impediment to the sector's development. Because green leaf must be processed within six hours of plucking, rehabilitation of feeder roads used for transporting green leaf from farms to factories must be given priority. But most of the infrastructure problems (such as poor quality of the national road system and frequent disruptions in electricity supply) are not specific to the tea sector and need to be dealt with at a broader level. While improvement of infrastructure of a public goods nature needs public sector involvement, some infrastructure problems need to be resolved by the private sector, such as rehabilitating tea factories, building new ones, replacing transport equipment, and the like (Baffes, 2004; Kalu, 2001). Dutta (2011) in a study in India concluded that with an increase in the age of plantations, tea yield decreases. Also, tea yield is influenced by pruning, and fertilizer application and an empirical relationship exists between yield and leaf area index. Reter and Gibji (2016) there are many constraints in tea cultivation such as labour problem, transportation, degradation of soil, climatic constraints, and plant diseases (Molua, 2012).

Relating Tea production to motivation, it can be noted that, motivation is considered as the set of processes that arouse, direct and maintain human behaviour towards attaining goals. There are several factors that motivate a person to work. The motivational factors can be broadly divided into two groups; monetary and non-monetary factors. The monetary factors include among others, salaries or wages. Salaries or wages is one of the most important motivational factors. Reasonable salaries must be paid on time and while fixing salaries the organization must consider elements such as; cost of living, company ability to pay, capability of company to pay etc. Added to salaries, there are bonuses and incentives which can be used as elements to motivated workers. Bonus refers to extra payment to employee over and above salary given as an incentive. An organization may also provide additional incentives such as medical allowance, educational allowance, etc. Special individual incentives can also be used. Such incentives are to be given to deserving employees for giving valuable suggestions (Sasson, 2017).

According to Robins and Mary (1996), lack of motivational factors has been a major hindrance on employees performance, lack of motivational factors like job security, training, enough salary, compressed work which have favorable effects on employees job satisfaction and productivity and lack of flexible time which provides employees with time for pursuing their hobbies or taking care of family all have effect on performance. Akitonye (2000) asserts that money remains the most significant motivational strategy. As far back in 1991, Fredrick Taylor and his scientific management associate describe money as the most important factor in motivating industrial workers to achieve greater productivity. Taylor advocated for the establishment of incentive wage of stimulating workers to high performance, commitment and eventually satisfaction. Money possesses significant motivational power in as much as it symbolizes intangible goals like security power, prestige and a feeling of accomplishment and success.

Appelbaum et al (2000) demonstrates the motivational power of money through the process of job choice. He explains that money has the power to attach, retain and motivate individuals towards higher performance. For instance, if an information professional has another job offer which has identical characteristics with his current job but greater financial rewards, the worker would in all probability be motivated to accept the new job offer. Oroni et al (2014) states that many managers use money to reward or punish workers. This is done through the process of rewarding employees for higher productivity by instilling fear of loss of job (premature retirement) due to poor performance. The desire to be prompted and earn enhanced pay may also motivate employees. Greater use of motivation enhancing practices such as incentives and other rewards for performance practices satisfy competence and relatedness needs, thus resulting in increased affective commitment. Such practices signal a positive valuation of employees and their efforts by the company (Appelbaum et al., 2000). Task and outcome performance followed by rewards convey signals of competence. Incentive plans create feelings of group and organizational belonging that enhances intrinsic motivation.

Oroni et al (2014) from a study in Kenya established that bonuses in the tea factories in the county is not effective and efficient, the motivation policy in the tea factories is not satisfactory. They also 
established that most of the tea factories lacked a structured promotion policy system in place and this aspect could be a de-motivating factor in the tea factories in the county. In addition, it was established that rewards are minimally used in the tea factories in the county. However, to some extent rewards and remuneration are commonly given as a form 2 of motivation in the tea factories in spite of some resentment among some tea factory employees in the county. They hold that motivation of employees is not adequately addressed in tea factories to equip them with what is expected of them in the field to perform effectively. Also, their findings revealed that poorly motivated employees perform minimally.

\section{THEORETICAL FRAMEWORK}

In the study, we adopt the framework of Hertzberg two factor theory as initially presented by Oroni et al (2014). This theory is also known as intrinsic/extrinsic motivation theory which state that certain factors in the workplace result in job satisfaction, but if absent, lead to dissatisfaction (Oroni et al., 2014). The author assets that the factors that motivate people can change over their lifetime, but "respect for me as a person" is one of the top motivating factors at any stage of life. Hertzberg distinguished between motivators; for example challenging work, recognition and responsibility which give positive satisfaction, and hygiene factors; for example status, job security, salary and fringe benefits that do motivate if present, but, if absent, result in de-motivation (Oroni et al., 2014) . The name Hygiene factors is used because, like hygiene, the presence will not make you healthier, but absence can cause health deterioration. This theory is still valid in the contemporary world for instance; Duening and Ivancevich (2003) observed that hygiene factors are those that result in dissatisfaction of employees which also include salary, working conditions, policies and administration of companies and interpersonal relation. On motivation and wages as stated by Hertzberg (1959), high payment of salaries makes employees to develop interest in their work and stop absenting themselves from duty. This is because money is a motivator to the employees. Therefore, this study determined the influence of motivation on tea factory employee performance the Djuttitsa tea estate performance as stipulated in the Herzberg's two-factor theory (Sasson, 2017).

This theory can equally be associated with that of Hertzberg (1959) which is based on the assumption that people are motivated by a series of five universal needs. Maslow (1959) in his hierarchy of needs stated that human beings including employees have five hierarchies of need for them to survive. These needs are ranked, according to the order in which they influence human behaviour, in hierarchical fashion. These needs are physiological, safety, social, esteem and self actualization needs (Hubert, 1973). As already demonstrated in the literature, Hubert (1973) noted that, Physiological needs are the need at the bottom of the triangle and include the lowest order need and most basic. This includes the need to satisfy the fundamental biological drives such as food, air, water and shelter. According to Maslow organisations must provide employees with a salary that enable them to afford adequate living conditions. The rationale here is that any hungry employee will hardly be able to make much of any contribution to his organisation. The safety needs occupies the second level of needs. Safety needs are activated after physiological needs are met. They refer to the need for a secure working environment free from any threats or harms. The rationale is that employees working in an environment free of harm do their jobs without fear of harm (Sasson, 2017).

The social needs represent the third level of needs. They are activated after safety needs are met. Social needs refer to the need to be affiliated (i.e. the needed to be loved and accepted by other people). To meet these needs organisations encourage employees' participation in social events such as picnics, organisations bowling etc. While esteem needs represents the fourth level of needs. It includes the need for self-respect and approval of others. Organisations introduce awards banquets to recognise distinguished achievements. Finally, self - actualisation occupies the last level at the top of the triangle (Sasson, 2017). This refers to the need to become all that one is capable of being to develop ones fullest potential. The rationale here holds to the point that self-actualised employees represent valuable assets to the organisation human resource. Oroni et al (2014) argue that substantial remuneration in terms of salaries satisfy all the above human needs. If the salaries are low, then the employees become discouraged and may lead to laxity resulting to absenteeism and low productivity. Going by their assertion, this study examines the influence of motivation on the Djuttitsa tea estate performance (Hubert, 1973).

\section{MeThodology}

The Djuttitsa Tea Estate Plantation is found in Cameroon with geographical coordinates $5^{\circ} 35^{\prime} 0^{\prime \prime}$ North, $10^{\circ} 5^{\prime} 0^{\prime \prime}$ East. The Estate saw the light of day in 1977 through a Prime Ministerial Decree. The 
tea occupies 446.56 hectares surrounded by eucalyptus trees that are used for fuel in the tea factory and as wind break. The average annual rainfall over a period of 10 years is about $1717.7 \mathrm{~mm}$ with a maximum of $2000.1 \mathrm{~mm}$ for 160 days registered in 2005 and a minimum of $1372 \mathrm{~mm}$ for 112 days in 2008.

A linear production function is used to assess the effect of motivation on tea production. The functional form of the function is as follows:

$$
T P=\mu_{0}+\lambda_{1} M+\lambda_{2} T+\lambda_{3} R f+\varepsilon_{i}
$$

Where: $T P_{i}$ represents tea production (quantity of made tea produced in $\mathrm{kg}$ ) for period $i$ (for each month), $M$ represents motivation (measured by total monthly wage expenses), $T$ represents monthly temperature, and $R f$ represents rainfall, $\varepsilon_{i}$ is a random error term and the intercept is represented by $\mu_{0}$. The coefficient $\lambda_{1}$ is the parameter of primary interest and represents the impact of motivation on tea production. The coefficients of the variables used in the study were estimated with the use of the OLS regression technique to assess the effect of motivation on tea production. The regression was conducted with the mode of Robust Standard Error (RSE) because this mode deals with minor problems about failure to meet some assumptions of OLS such as: minor problems about normality, autocorrelation, heteroskedasticity, multicollinearity and observations exhibiting large residuals (Jann, 2012). With this mode of RSE, the point estimates of the coefficients are exactly the same as in OLS. The only difference is that standard errors take into account issues concerning heterogeneity and lack of normality. The Robust mode minimizes the variance of the residuals and when there is no heteroskedasticity, the RSE simply become OLS standard errors (Hubert, 1973). To test for statistical significance of the parameters estimated, the t-statistics, and the p-value were used and the conventional $\mathrm{R}^{2}$ was considered as a measure of goodness of fit. Lastly, the Fisher F-statistic was used to verify for the joint significance of the variables included in the models.

\subsection{Data Presentation}

The study population consists of tea pluckers, factory workers, garage workers and the administrative personnel of the CTE Djuttitsa Plantation, not leaving out wholesalers, retailers and consumers. The sampling techniques used were the stratified sampling and the stratified random sampling. This choice is motivated by the fact the tea plantation is divided into three sections: the South, East and Central sections, where the workers would be chosen through simple random sampling as well as in the factory and garage. However certain key personalities holding administrative positions would be automatically interviewed

Questionnaire was prepared to collect primary data was elaborated around a list of precise points that were related to the theme or topic of the study. The questionnaire consisted of combinations of both open and close-ended questions and information obtained through the questionnaire provided data on the variables to be used in the study. The questionnaire was pre-tested on ten respondents making up different components of workers. After the pre-test, there was need to produce another copy of the questionnaire in French for the francophone respondents. Furthermore some questions proved irrelevant and were scraped while others were rephrased. The questionnaire was therefore pretested, adjusted and validated before being administered to the tea pluckers, factory workers, workers at the engineering section, and the administrative personnel of the CTE Djuttitsa Plantation. Information gotten from secondary sources of data was based on the role of the various actors in the tea value chain; monthly production of green leaf, made tea, temperature, and rainfall for each month for the past 10 years (2007 to 2016) was sorted together with the labour costs (wage expenses) for the same period from the different records of CTE Djuttitsa. Research was also done in the internet, review of relevant books, journals, articles with a view of tapping information and concepts related to the study.

The analytical tools adopted in this study consist of both descriptive and inferential methods of analysis. The descriptive statistics consist of the use of percentages, frequency tables, measures of central tendency and pie charts. The inferential statistics consist of the use of econometric regression technique and the technique used here is the Ordinary Least Square (OLS) regression method. To analyse the Djuttitsa tea estate value chain; that is to identify the various actors of the Djuttitsa tea estate value chain and the role they play in the value chain, a value chain map was used. Secondly, descriptive statistics through the use of pie charts, frequency distribution tables and percentiles were 
used to present the various measured used by the administration of the organisation to motivate workers and represent the number and proportion of respondents who have received or benefited from such measures. Added to this, measures of central tendency will be used to describe the prevailing climatic conditions at the Djuttitsa Tea Estate. To determine the extent to which motivation affects tea production, the OLS estimation technique was used. Here, the quantity of made tea produced was regressed against the enterprises' wage expenses, temperature and rainfall.

\section{EMPIRICAL RESUlT}

\subsection{Socio-Professional Characteristics of Employees}

Workers' socio-professional characteristics are very important as they have an effect on the latter's motivation and attitude at work, they affect their performance and productivity and likewise that of the company as a whole. Hence a brief description of the respondents' socio-professional characteristics is a prerequisite for this study. The social characteristics are presented in Table 2 . The results presented in table 2 above reveal that $62.8 \%$ of the respondents are male against $37.2 \%$ female. It is also revealed that only $21.5 \%$ of the sampled employees are less than 30 years old, however, $73.6 \%$ are married but only $5.8 \%$ went above secondary school level to attend university studies and a slight majority of the respondents have relatively large families with $58.7 \%$ who have more than six children.

Table2. Distribution of Respondents According to Selected Professional Characteristics

\begin{tabular}{|c|c|c|c|}
\hline Characteristics & Modalities & Frequency & Percentage \\
\hline \multirow[t]{3}{*}{ Gender } & Male & 76 & 62.8 \\
\hline & Female & 45 & 37.2 \\
\hline & Total & 121 & 100 \\
\hline \multirow[t]{6}{*}{ Age Distribution } & $<30$ & 26 & 21.5 \\
\hline & $31-40$ & 28 & 23.1 \\
\hline & $41-50$ & 38 & 31.4 \\
\hline & $51-60$ & 27 & 22.3 \\
\hline & $>60$ & 2 & 1.7 \\
\hline & Total & 121 & 100 \\
\hline \multirow[t]{3}{*}{ Work Status } & Permanent & 54 & 44.6 \\
\hline & Casual & 67 & 55.4 \\
\hline & Total & 121 & 100 \\
\hline \multirow[t]{4}{*}{ Marital Status } & Married & 89 & 73.6 \\
\hline & Single & 30 & 24.8 \\
\hline & Widow(er) & 2 & 1.7 \\
\hline & Total & 121 & 100 \\
\hline \multirow[t]{4}{*}{ Level of Education } & Primary & 70 & 57.9 \\
\hline & Secondary & 44 & 36.4 \\
\hline & Tertiary & 7 & 5.8 \\
\hline & Total & 121 & 100 \\
\hline \multirow[t]{4}{*}{ Family Size } & $<6$ & 50 & 41.3 \\
\hline & $6-10$ & 60 & 49.6 \\
\hline & $>10$ & 11 & 9.1 \\
\hline & Total & 121 & 100 \\
\hline \multirow[t]{6}{*}{ Years of Service } & $<5$ years & 32 & 26.4 \\
\hline & 5-9 years & 10 & 8.3 \\
\hline & $10-14$ years & 28 & 23.1 \\
\hline & $15-20$ years & 21 & 17.3 \\
\hline & $>20$ years & 30 & 24.8 \\
\hline & Total & 121 & 100 \\
\hline
\end{tabular}

Source: Author

The results presented in table 3 indicate that a majority (55.4\%) of respondents are casual workers against $44.6 \%$ who are permanent workers. Only $26.4 \%$ of these respondents have less than five years of service at the Djuttitsa Tea Estate. The results also reveal that a large majority of the workers at Djuttitsa are employed at the plantation section with $62 \%$ of the respondents who work at plantation followed by $12.4 \%$ who work at the factory section, $10.7 \%$ at other positions (mainly security), $9.1 \%$ who are office workers and $5.8 \%$ who work at the engineering section. 


\subsection{Nature of Motivation in Agricultural Enterprise}

Motivation is established by numerous theories and empirical works as an important instrument in organisational management. Motivation of workers in any organization is recognized as important to drive workers to achieve organizational goals. This is the reason why the measures and motivation policy applied by the Djuttitsa CTE administration is of interest in this study. The motivational factors applied by the organization and their rate/mode of usage are presented in this section.

Through theories and empirical investigations, money recognised as a motivator to employees. According to Maslow organisations must provide employees with a salary that enable them to afford adequate living conditions because any hungry employee will hardly be able to make much of any contribution to his organisation and this will adversely affect the organisation's overall performance. An analysis of the salaries offered to the sampled employees is presented in table 3 . The results presented in table 3 indicate that $9.1 \%$ of respondents receive salaries below 60USD a large majority; $82.6 \%$ receive a pay package ranging from $60-100$ USD and only $8.3 \%$ earn salaries of more than 100USD. Also, it is revealed that $19 \%$ of respondents have had their salaries drop over time, $20.7 \%$ have seen their salaries remain unchanged and a large majority; $59.5 \%$ have witnessed an increase in their salaries over time.

Table3. Usage of Annual leave and leave allowance as motivator

\begin{tabular}{|c|c|c|c|}
\hline Tools & Modalities & Frequency & Percentages \\
\hline \multirow{4}{*}{$\begin{array}{l}\text { Wages } \\
\text { (USD) }\end{array}$} & $<60$ & 11 & 9.1 \\
\hline & $60-100$ & 100 & 82.6 \\
\hline & $>100$ & 10 & 8.3 \\
\hline & Total & 121 & 100 \\
\hline \multirow{4}{*}{$\begin{array}{l}\text { Changes Wage } \\
\text { (USD) }\end{array}$} & Decrease & 24 & 19.8 \\
\hline & No Change & 25 & 20.7 \\
\hline & Increase & 72 & 59.5 \\
\hline & Total & 121 & 100 \\
\hline \multirow[t]{3}{*}{ Annual Leave } & Yes & 47 & 38.8 \\
\hline & No & 74 & 61.2 \\
\hline & Total & 121 & 100 \\
\hline \multirow[t]{3}{*}{ Social Insurance } & Yes & 53 & 43.8 \\
\hline & No & 68 & 56.2 \\
\hline & Total & 121 & 100 \\
\hline \multirow[t]{3}{*}{ Leave Allowance } & Yes & 47 & 38.8 \\
\hline & No & 74 & 61.2 \\
\hline & Total & 121 & 100 \\
\hline \multirow[t]{3}{*}{ Protection at work } & Yes & 21 & 17.35 \\
\hline & No & 100 & 82.65 \\
\hline & Total & 121 & 100 \\
\hline \multirow[t]{3}{*}{ Promotion } & Yes & 47 & 38.8 \\
\hline & No & 74 & 61.2 \\
\hline & Total & 121 & 100 \\
\hline \multirow[t]{3}{*}{ Recognition } & Yes & 50 & 41.3 \\
\hline & No & 71 & 58.7 \\
\hline & Total & 121 & 100 \\
\hline \multirow[t]{3}{*}{ Reward for Overtime } & Yes & 25 & 20.7 \\
\hline & No & 96 & 79.3 \\
\hline & Total & 121 & 100 \\
\hline \multirow[t]{3}{*}{ In-Service Training } & Yes & 35 & 28.9 \\
\hline & No & 86 & 71.1 \\
\hline & Total & 121 & 100 \\
\hline
\end{tabular}

\section{Source: Author}

Going by the above results it is observed that the wage rates offered by the organisation are relatively low and not quite motivating because Oroni et al (2014) argue that substantial remuneration in terms of salaries satisfy all the above human needs. If the salaries are low, then the employees become discouraged and may lead to laxity resulting to absenteeism and low productivity. However, a good proportion of the respondents have received salary increments and this is a good motivating factor. Social insurance and work protection (safety at work) appear amongst the safety needs going by the 
Maslow hierarchy of needs. The rationale is that employees working in an environment free of harm do their jobs with more enthusiasm. The results presented in Table 3 reveal that only $43.8 \%$ of the respondents are registered at the National Social Insurance Fund against $56.2 \%$ who are not. And only the $43.8 \%$ could be beneficiaries of social insurance services in case of need. Table 3 presents the proportion of respondents who have protection equipments at work and the contents of the figure indicate that only $17.36 \%$ of the respondents are provided with protective equipments at work. This may tend to de-motivate workers who are exposed to risks of accidents during work.

The presence of annual leave for workers and the availability of an allowance during this leave is an important motivator for workers in every organisation. This is because workers can be free to put in all their resources (physical and intellectual) at the disposal of the organisation knowing that there will be time for them to recover and make-up their strengths with an allowance for such. The results presented in table 3 reveal that $38.8 \%$ of respondents benefit from annual leave and this same proportion of respondents receive leave allowances. The Esteem needs proposed by Maslow include the need for self-respect and approval of others. Organisations introduce awards banquets to recognise distinguished achievements. Also, Hertzberg in his theory distinguished between motivators; such as challenging work, recognition and responsibility which give positive satisfaction. Moreover, Frederick Herzberg's two-factor theory assets that the factors that motivate people can change over their lifetime, but "respect for me as a person" is one of the top motivating factors at any stage of life. Hence, respect for workers as persons, recognition for performance and distinguished achievements are vital to motivate workers in every organisation. The survey conducted at the Djuttitsa CTE, reveals that $38.8 \%$ of respondents have received promotions at their services and $41.3 \%$ of these respondents declared having received praises and recognitions for their performance from hierarchy.

The provision of awards/remuneration for overtime and in-service training in any organisation tend to act as significant motivators for employees. This is because the former provides a supplementary earning and encourages workers to work overtime when need arises and the latter enables the workers improve upon their skills and abilities. The usage of overtime reward and in-service training at the Djuttitsa CTE is presented in the table that follows. The results presented in table 3 indicate that only $20.7 \%$ of the respondents have received rewards for overtime and only $28.9 \%$ have been exposed to in-service training as workers of the Estate.

\subsection{Employee Motivation and Enhancement of Agricultural Enterprise}

The results obtained from the regression are presented in table 9 and reveal that a wage expense which is the measure for motivation in the context of this study has a positive and significant contribution to tea production in the Djuttitsa tea estate. These results also indicate that rainfall and temperature have positive and significant effects on tea production in the area of study. The results also reveal that tea production is determined at $72.96 \%$ by the variables included in the model, judging from the Rsquared. Hence, $72.96 \%$ change in quantity of made tea produced is determined by wage expense, rainfall and temperatures whereas the remaining $27.04 \%$ changes are determined by other factors not included in the model. These results have their overall significance at $1 \%$ level hence; there is a $99 \%$ certainty of the reliability of the overall results.

Table4. Presentation of OLS Regression Results

\begin{tabular}{|c|c|c|c|c|}
\hline \multicolumn{5}{|c|}{ Dependent Variable: Tea Production in kg } \\
\hline Independent Variables & Coefficient & Standard error & T-statistic & P-value \\
\hline Wage & $0.0067681 * * *$ & 0.000399 & 16.93 & 0.000 \\
\hline Rainfall & $62.58532 * * *$ & 22.08140 & 2.83 & 0.005 \\
\hline Temperature & $7461.442 * * *$ & 2602.397 & 2.87 & 0.005 \\
\hline Experience & $0.06031 * * *$ & 0.028314 & 2.13 & 0.051 \\
\hline Education & $0.01385 * * *$ & 0.003181 & 4.35 & 0.000 \\
\hline Permanent status & $0.0362 *$ & 0.019153 & 1.89 & 0.056 \\
\hline Casual status & 0.00198 & 0.132000 & 0.15 & 0.827 \\
\hline Family size & $-0.00347 * * *$ & 0.000963 & -3.60 & 0.001 \\
\hline Constant & $-216693.5 * * *$ & 51530.26 & -4.21 & 0.000 \\
\hline Number of Observations & & 120 & & \\
\hline $\mathrm{F}(3,116)$ & & 99.51 & & \\
\hline Prob F-statistics & & 0.0000 & & \\
\hline R-Squared & & 0.7296 & & \\
\hline
\end{tabular}

Source: Author, Note: $* * * * *$ and $*$ indicate $1 \%, 5 \%$ and $10 \%$ levels of significance, respectively 
Specifically, the results obtained from the regression reveal that wage expense has a positive and significant effect on the quantity of tea produced with a coefficient of 0.0067681 and significant at $1 \%$ level. This coefficient implies that; if the amount of wage expense is raised by 1 F.CFA, the quantity of made tea produced will increase by $0.0067681 \mathrm{~kg}$. Likewise, if the amount of wage expense is raised by 1000 F.CFA, the quantity of made tea produced will increase by $6.77 \mathrm{~kg}$. This result is in accordance with the postulate of the hierarchy of needs theory. Since Maslow held that organisations must provide employees with a salary that enable them to afford adequate living conditions because any hungry employee will hardly be able to make much of any contribution to his organisation

This result confirms the assertion made by Robins and Mary (1996) that lack of motivational factors has been a major hindrance on employees' performance. According to Robins and Mary, lack of motivational factors like job security, training, enough salary, compressed work which have favorable effects on employees job satisfaction and productivity and lack of flexible time which provides employees with time for pursuing their hobbies or taking care of family all have effect on performance. In addition, the result is can be backed by Akitonye (2000) who made the assertion that money remains the most significant motivational strategy. Also, Fredrick Taylor and his scientific management associate describe money as the most important factor in motivating industrial workers to achieve greater productivity. Taylor advocated for the establishment of incentive wage of stimulating workers to high performance, commitment and eventually satisfaction. Money possesses significant motivational power in as much as it symbolizes intangible goals like security power, prestige and a feeling of accomplishment and success.

Moreover, the result is in line with the findings of Sinclair et al (2005) who demonstrated the motivational power of money through the process of job choice. He explained that money has the power to attach, retain and motivate individuals towards higher performance. Added to this, the result corroborates the findings of Bouddih (2003) who conducted a study in Sri-Lanka and their findings revealed that the financial benefits that is; salary, allowances, salary increments, among others provided by the management company for labourers are highly affected to the improvement of labour productivity through the increase of labour satisfaction. The result is also in line with Oroni et al (2014) who argued that substantial remuneration in terms of salaries satisfies numerous human needs. Therefore, if the salaries are low, then the employees become discouraged and may lead to laxity resulting to absenteeism and low productivity.

The findings of this study also revealed that; the prevailing climatic conditions (rainfall and temperature) have positive and significant effects on the production of made tea by the Djuttitsa tea estate. Specifically, rainfall has a coefficient of 62.58 which implies that if the amount of rainfall is increased by $1 \mathrm{~mm}$, the quantity of made tea will increase by $62.58 \mathrm{~kg}$. Likewise, temperature has a coefficient of 7,461.442 which implies that if the temperature $\mathrm{n}$ average increase by $1^{\circ} \mathrm{C}$, the quantity of made tea will increase by $7461.4 \mathrm{~kg}$. These results corroborates those of Gana (2000) who held that there are many constraints in tea cultivation such as climatic constraints, labour problem, transportation, degradation of soil, and plant diseases. The results are also supported by the fact that the average rainfall (humidity) prevailing at Djuttitsa stands at $134.17 \mathrm{~mm}$ which is below the optimum rainfall of $150 \mathrm{~mm}$. Likewise, the average temperature prevailing at Djuttitsa is $17.73^{\circ} \mathrm{C}$ which is close to the above the minimum temperature suitable for tea production but is below the optimum range of $18-30^{\circ} \mathrm{C}$.

This section was aimed at assessing the extent to which motivation affects tea production at the CTE Djuttitsa. The variable salary expense was used as a proxy to measure motivation and the quantity of made tea produced to capture tea production. The hypothesis to be tested (null hypothesis) here was that; workers' motivation does not affect tea production at the CTE Djuttitsa. Judging from the results obtained, this hypothesis is rejected given that salary expenses have a positive and significant effect on tea production at $1 \%$ level. Temperature and rainfall were found as other factors that affect tea production at the CTE Djuttitsa.

\section{CONCLUSION}

The study sought to assess the various measures used by the tea estate to motivate their workers, describe the prevailing climatic conditions at the Djuttitsa Tea Estate and determine the extent to which motivation affects tea production. To achieve these objectives, primary data were collected from 121 workers of the estate as well as secondary data covering each month for the period 2007 to 
2016. The data was analysed using SPSS and STATA software. The analyses involved the use descriptive statistics and the OLS regression technique.

The findings highlight the fact that a wide range of motivators are being used by the Djuttitsa tea estate administration mainly; salaries and salary changes, with only $8 \%$ of the respondents earning more than 50,000 F.CFA and 59.5\% of respondents who have witnessed salary increase through time; only $43.8 \%$ of the respondents are registered with the National Social Insurance Fund and $17.36 \%$ have protection material at work; $38.8 \%$ of respondents benefit from annual leave and this same proportion receive leave allowances; $38.8 \%$ of sampled workers have received promotions and $41.3 \%$ declared having received praise and recognition from the hierarchy due to their performance.

Moreover, the results obtained from the analyses revealed that the average temperature and precipitation/humidity prevailing in the study area stand at $134.17 \mathrm{~mm}$ and $17.73^{\circ} \mathrm{C}$ respectively and are slightly below the optimum required for sustainable tea production. To assess the extent to which employees' motivation affects tea production, the OLS regression was employed and findings revealed that motivation through wage expenses has a positive and significant effect on tea production at $1 \%$ level of significance. Temperature and rainfall were found as other factors that affect tea production at the Djuttitsa tea estate. After investigations and analyses, the study concludes that; the CTE Djuttitsa value chain is well organised. However, the wages offered to the workers are very low, few workers are provided with protection material at work, annual leave and leave allowance are minimally used to motivate workers as well as promotions, praise and recognition.

In a nut shell, the motivation policy of the tea estate is not satisfactory since the enterprise lacks a well structured motivation policy system. Therefore, the motivation of employees is not adequately addressed in the tea estate to equip them with what is expected of them in the field to perform effectively. Given the positive significant effect of motivation on tea production, motivation can be considered as a tool if well managed and properly used will urge workers to put in their best to contribute to the productivity and growth of the tea estate. Considering the relevance of the tea subsector in the economy and the importance of workers' motivation as a tool in achieving the organization's goals, the following recommendations are made based on the results of this study and on the experience of the six months' internship in CTE Djuttitsa.

\section{REFERENCES}

[1] Achiri R (2015): Impact of age and management factors on tea yield and modelling the influence of leaf area index on yield variations. ScienceAsia vol $37 \mathrm{pp} 83-87$

[2] Akitonye B (2000): A summary of motivation theories. Accessed from http://www.Yourcoach.be /en /employee-motivation-ebook/ on 18-05-2017

[3] Appelbaum E, Bailey T, Berg P, Kallenberg A (2000): Manufacturing advantage: Why high-performance work systems pay off. Ithaca, NY: Cornell University Press.

[4] Ayissi M, Nkwain S, and Njwe R (1988): Food marketing/transportation system in Cameroon. USAID, Yaounde, Cameroon.

[5] Baffes J (2004): Tanzania's Tea Sector: Constraints and Challenges in a Global Environment, Africa Region Working Paper. www.worldbank.org/afr/wps.

[6] Bouddih A (2003): Privatisation and labour militancy:The case of Cameroon tea estate, Bamenda: Neba publisher, , 26(1),p.51-7

[7] Clifford $\mathrm{M}$ and Willson K (eds.): Tea - Cultivation to consumption. London, Chapman and Hall, p87-130

[8] Dutta J (2011): The flowering plants handbook. Hertford, Plant Gateway, 619p.

[9] Duening and Ivancerish (2003): Production quantities by nation. Quarterly Journal of International Agriculture 46 (2007), No. 3: P. 221-239

[10] Gana R (2000): Constrains of marketing agricultural products: An Introduction. Bamenda: Tarfora.

[11] Hubert P (1973): Robust regression: Asymptotics, conjectures, and Monte Carlo. The Annals of Statistics, 1(5): 799-821

[12] Jann B (2012): Robust Regression in STATA: $10^{\text {th }}$ German STATA user Group Meeting. Berlin, June 1, 2012.

[13] Kalu P (2001): Labor militancy; An introduction. Division for Policy and Socio-economic Analysis, Buea: CDC.

[14] Molua E (2012): Rural development and agricultural progress: Challenges, Strategies and Cameroonian Experience. Discussion papers, Institute of Rural Development, University of Goettingen, Germany 
[15] Nkwain S, Ayissi M and Numfor F A (1993): Review Of Documentation On Cameroon's Food Crop Production, Processing And Marketing prepared for the Agricultural and Rural Development Office USAID Cameroon August 1993

[16] Oroni R, Iravo M, Munene C (2014): Influence of Motivation on Tea Factory Employee Performance in Kenya. A Case of Kisii County Journal of Business and Management Volume 16, Issue 4. Ver. II PP 36-41

[17] Robin P and Gibji N (2016): Status and constraints of tea cultivation in Lohit District of Arunachal Pradesh, India International Journal of Current Science V. 19(1): E 146-155

[18] Sasson R (2017): The Meaning of Motivation, Accessed from http:// www. Success consciousness. com/strengthen_motivation.htm - on 18-05-2017

Citation: Mbu Daniel Tambi, Ngefack Edward Azem, “ Employee Motivation and the Promotion of Agricultural Enterprise” International Journal of Research Studies in Agricultural Sciences (IJRSAS), 2019; 5(6), pp. 22-32, http://dx.doi.org/10.20431/2454-6224.0506003

Copyright: (C) 2019 Authors. This is an open-access article distributed under the terms of the Creative Commons Attribution License, which permits unrestricted use, distribution, and reproduction in any medium, provided the original author and source are credited. 